\title{
Contributions of social language practices to the learning of reading and writing in primary education
}

Contribuições das práticas sociais da linguagem para a aprendizagem da leitura e escrita do ensino fundamental

\author{
Everaldo Do Nascimento \\ Autonomous University of Asunción (UAA), Paraguay \\ everaldon31@gmail.com \\ Clara Roseane Da Silva Azevedo Mont'Alverne \\ Federal University of Pará -UFPA, Brazil \\ clarazevedo@globo.com
}

Fecha recepción: 01-02-2020

Páginas 26-35

Fecha aceptación: 20-05-2020

\begin{abstract}
.
The main objective of this article is to highlight the contributions of the social practices of language in the teaching and learning process of reading and writing in primary education. In the methodological aspect, we conducted a thorough bibliographic review in order to understand the contributions of these social practices of language and their contributions to education. We point out the readings that deal with this theme, based on the authors who highlight these aspects focused on the social practices of language. Of which we highlight Freire (2011), which addresses concepts on learning; Soares (2017), which clarifies the influence of culture on the learning process, Also Vieira (2020), which provides us with indicative appraisals on the educational discourse for a transformative school.
\end{abstract}

Keywords: educational practices, elementary school, social education, reading and writing

\section{Resumo.}

O presente artigo tem como objetivo principal destacar as contribuições das práticas sociais da linguagem no processo de ensino e aprendizagem da leitura e escrita do ensino fundamental. No aspecto metodológico, realizamos uma revisão bibliográfica minuciosa, no sentido de compreender as contribuições destas práticas sociais da linguagem e seus aportes voltados para educação. Assinalamos as leituras que trata essa temática, com base nos autores que destacam estes aspectos voltados as práticas sociais da linguagem. Dos quais destacamos, Freire (2011), que aborda conceitos sobre a aprendizagem; Soares (2017), que nos esclarece sobre a influência da cultura sobre o processo de aprendizagem, Também, Vieira (2020), que nos brinda 
com apreciações indicativas sobre o discurso educativo para uma escola transformadora.

Palavras Chaves: práticas educativas, ensino fundamental, educação social, leitura e escrita

\section{Introduction.}

In this work we have objectives to carry out the bibliographic review concerning the contributions of the social practices of language in the teaching and learning process of reading and writing in primary education, with the purpose of covering this process and highlight this learning in the methodological sense of acquiring reading and writing. According to Demo (1991) provoking, challenging, stimulating, is a way to stimulate student learning in the educational process, in order to enable action to establish meaningful learning. It is also necessary to satisfy their needs even if they are not conscious at first, i.e. that the learning of reading and writing happens in an appropriate and natural way.

We seek to enable the concepts of educational practices aimed at learning to read and write. Learning this, that the school has a great responsibility to systematize. Therefore, we cannot attribute all the blame to the teacher alone, as there are several factors that compromise the teaching-learning process, such as, for example, the physical aspects of the school, working conditions, among others.

And above all, to awaken a critical reflection on the theme in question, where we can reflect on our role as educator and facilitator of teaching. And we understand that we must act in a clear and precise way seeking to develop an education with a methodology that involves the reader in a meaningful way in the learning process.

\section{Contributions of social language practices to primary education.}

Throughout the history of education, the position of individuals in the social hierarchy is determined by their personal characteristics, and in the course of time it is understood that social differences would have their origin in differences in abilities. Thus, students from the lower classes are more likely to fail at school, and in a way belong to these classes precisely because they are less gifted, less apt, less intelligent than those who would not fail, and would have easy access to the privileged classes.

In the 1970s in Brazil, when the ideology of cultural disability stabilized, coinciding with the time when the possibilities of access to school by children from the working classes grew, the learning difficulties of these children have been attributed, in the pedagogical discourse, to the humility of their cultural context and the deficiencies which would result from it: affective needs, cognitive difficulties, linguistic disability. Therefore, this ideology of cultural disability which reflects in learning difficulties is still present in the early decades of the 21st century, both in the United States, where it originated, and in Brazil (Brazil, 1988). 
For Soares (2017, p. 33): the theory of cultural deficiency states that children from the working classes arrive at school with a deficient language, which prevents them from being successful in learning activities in the different fields of knowledge. And according to the author, these children have a poor vocabulary, use incomplete sentences, their syntax is confusing and inadequate to the expression of logical thought; they commit failures of agreement, regency, pronunciation. Another aspect is that they communicate through non-verbal resources than through verbal resources. That is, children are seen as linguistically limited.

In this context, the logic of this theory, the linguistic deficiency is attributed to the cultural deficiency of the linguistic context in which the child lives, particularly in the family environment. In this sense, Soares $(2017$, p. 35$)$ states about this theory of cultural deficiency, that children from the working classes, unlike children from the favoured classes, present a "linguistic deficiency", being thus, this factor one of the responsible for a great part of the learning difficulties of this child at school.

In view of the above, it is understood that at one point the three theories agree: they affirm the existence of a distance between the language of individuals belonging to socially and economically privileged groups and that of individuals belonging to the disadvantaged, whether this distance translates into a deficiency of one language in relation to the other, or into differences between them, or into oppression of one over the other.

And it is this distance that can explain what has been considered a failure in the learning and use of the language in the early years of primary education in our Brazilian public schools. Therefore, we seek to develop this study, and reinforce the importance of language in the context of social practices of language. In view of this, it is pertinent to reflect on language as an interaction process, in the teaching and learning of reading and writing (Freire, 2011).

\section{Social language practice.}

In this respect, the social practice of language is understood as consumption, and not as the production of theories, arising from the demand for the application of theories derived from traditional linguistics necessary for the teaching and learning processes of Language. Thus, the study of languages has broadened the field of research in Applied Linguistics and contributed to the multidisciplinarity of pedagogical performance in educational practices.

Therefore, language, whose reality is fundamental for verbal interaction, is an activity that, precisely because it only exists in relation to the other, is aimed at the concrete reality shared among human beings. And in this sense, we understand language as a key point of determining aspects basically by the form and character of social interaction between the participants of enunciation, to socialize and transmit thoughts and feelings. 
Reading and writing are important elements in our lives, and the school's function is to teach reading and writing, as well as educating for citizenship. Therefore, we should consider reading as an important process by which we understand written language. And for Mendonça (2011), writing requires the development of specific skills and an intellectual effort proportionately superior to the child's previous learning. for the author there are several ways of reading and interpreting texts or a note any of this will depend on the context in which the reading is inserted. And in this sense, the teacher must be explicitly clear about what content he or she wants the student to learn in order to be able to organize his or her strategies in order to contribute to the learning process of his or her students (Mendonça, 2011, p.26).

In the context of learning, the role of the teacher is also the main responsible for developing the child's cognitive and alleviating the learning difficulties presented by them. The acquisition processes of reading and writing by children are developing earlier and earlier, in view of the literate context in which we are immersed in contemporaneity. Reading and writing with competence has become an indispensable condition. Therefore, it is necessary to think of a suitable way to start this process already in early childhood education. It is known that the focus on Early Childhood Education is the use of language in social contexts as a form of insertion of the subject in culture, therefore, language. To experience language is to establish daily multiple interactions.

\section{Reading and Writing Practice in Primary School.}

In his work, the importance of the act of reading: in three articles that complete each other, whose common thread is reading, Freire (2011), shows us that, when well worked at school, it is a facilitator to develop writing, being the educator and his educational practice a determining factor in this learning process. Thus, contributing to the current discussions on the use of both oral and written discursive and textual genres.

According to Freire (1988), education in the initial series is constituted by the acquisition of reading, the emancipation of the subject in his active relationship with the world and everything around him. Therefore, the teacher, as a facilitator in this process of education, must be stimulated in the student collaboration, decision, participation and social and political responsibility. And in this term, this process of reading and writing practice in elementary school are distinct processes that interpenetrate.

Reading and writing are important elements in our lives, and the school's function is to teach reading and writing, as well as educating for citizenship. Therefore, we should consider reading as an important process by which we understand written language. And for Mendonça (2011), writing requires the development of specific skills and an intellectual effort proportionately superior to the child's previous learning. for the author there are several ways of reading and interpreting texts or a note any of this will depend on the context in which the reading is inserted. And in this sense, the teacher must be explicitly clear about what content he or she wants the student to learn in order to be 
able to organize his or her strategies in order to contribute to the learning process of his or her students (Mendonça, 2011, p.26).

From the perspective of language as a process of interaction, reading and writing are language skills extremely linked to the production of meaning. "Meaning is the consequence of the joining of different grammatical, social and textual knowledge, and also of cognitive practices". In the teaching-learning process, which refers to the reading and production of text, it will be given from the text". In such a way, it is now receiving a great prominence and protuberance. Within this context, the textual genres also receive an enormous projection. For example, in the classroom, reading and textual production begin to give prominence to their social function and their communicative pretension, as well as to their production context, their supports, their compositional structure and their linguistic factors (Brazil, 2020, p. 46).

In the context of reading and writing practice in elementary school, it is essential that the teacher plans writing situations with clear and diversified purposes and with the explicit explanation of the interlocutors of the text; respecting the difficulties of each individual, and that he carries out previous activities in order to develop reading and writing. In order for the practice to be meaningful, in the context of learning the role of the teacher also figures, this is the main responsible for developing the child's cognitive in alleviating the learning difficulties presented by them.

In the early years of primary school most students do not master this knowledge of reading and writing, an important point to take into account when we aim to develop innovative practices. Therefore, we must take into account that the acquisition processes of reading and writing of students are developing earlier and earlier, in view of the literate context in which we are immersed in contemporaneity. Reading and writing competently has become an indispensable condition. Therefore, it is necessary to think about an adequate way to start this process already in early childhood education. It is known that the focus on Early Childhood Education is the use of language in social contexts as a form of insertion of the subject in culture, therefore, language. To experience language is to establish daily multiple interactions (Brazil, 2020).

\section{Language in the early grades of elementary school.}

And language as a form of interaction, situations should be favored so that the student can make satisfactory use of the language in concrete situations of social interaction. Discussing the teaching of reading is always a priority theme in teacher continuing education programs. However, the bases of this work do not always converge. There is often an emphasis on the supposed "acquisition" of a "code", through training in phonemes, syllables or words. Such a conception is tied to an idea that if we teach the student to "decode", he will naturally become a reader. In line with such a concept of reading, it is common to use texts that have nothing to do with those circulating outside the school. For a long time now, researchers have been denouncing that this way of treating reading keeps children away from the social uses of writing. One consequence 
of this way of teaching is that the desire to read does not emerge in school. Moreover, "children get used to focusing their attention on deciphering words, without directing reading to the quest to build meaning in interaction with texts" (Albuquerque, 2014, p. 137).

In this sense, there have been very different orientations from the one described above. The defense prevails that it is necessary to conduct the teaching of reading based on the selection of authentic, integral and diversified texts (Brazil, 2020, p. 33). In this line of propositions, the mediation of the teacher is oriented so that the children learn ways of reading that show that the meaning of the text is not an automatic consequence of the identification of graphemes and their sound correspondences.

In the sense of language and its importance in the initial grades of elementary school, it has an important aspect mainly in the selection of the themes of the texts to be worked on. For Lajolo (2018), this aspect is due to the fact that in certain situations the texts are chosen simply because they are examples of a given textual genre, without there being a reflection on the content they express. In relation to this issue, we stress the need to face such a tendency that minimizes the de facto interactive action of the act of reading. If we think that, in literacy, the student learns to read and write, but also learns through reading and writing, then we will argue that reflections on textual genres are important insofar as they help the subject to understand the social practices of using reading and writing (Lojolo, 2018, 123).

Thus, it is important to highlight that in the early years of elementary school, no doubt the work aimed at children understanding the functioning of the writing system is a necessary dimension in teaching practice and needs to be approached in a systematic and playful way. The fundamental thing is that the action is planned with focus on what the students can learn to broaden their cultural horizons and act in society in a critical way, because when we teach to read, we also teach the contents treated in the texts that are read. To do so, according to the Brazilian Federal Constitution, we must begin to redesign our priorities when we teach to read and seek more connections with the non-school circuits where books and reading occur (Brazil, 2020).

Thus, promoting the learning of reading and writing from the social practices of language, in which the interaction appears as the center of a teaching process of the text considered as significant discourse, result of certain conditions of production, of a certain relationship between the interlocutors of reading and writing, being formatted in a textual genre, resembling to be an indispensable and fruitful path for pedagogical practice.

In short:

Table 1.-Contributions of social practices.

\begin{tabular}{|c|c|c|}
\hline \multicolumn{3}{|c|}{ Contributions of social language practices to primary education } \\
\hline DATE & AUTHOR & IDEA \\
\hline
\end{tabular}




\begin{tabular}{|c|c|c|}
\hline 1988 & $\begin{array}{l}\text { Federal } \\
\text { Constitution }\end{array}$ & $\begin{array}{l}\text { Art. 205. Education, the right of all and the duty of } \\
\text { the State and the family, shall be promoted and } \\
\text { encouraged with the collaboration of society. }\end{array}$ \\
\hline 1991 & Demo & $\begin{array}{l}\text { To provoke, to challenge, to stimulate, is a way to } \\
\text { stimulate students' learning in the educational } \\
\text { process, in order to enable action to establish } \\
\text { meaningful learning. }\end{array}$ \\
\hline 2011 & Mendonça & $\begin{array}{l}\text { The teacher should be explicitly clear about what } \\
\text { content he or she wants the student to learn in } \\
\text { order to be able to organize his or her strategies in } \\
\text { order to contribute to the learning process of his or } \\
\text { her students. }\end{array}$ \\
\hline 2014 & Albuquerque & $\begin{array}{l}\text { Children get used to focus their attention on } \\
\text { deciphering words, without directing reading to the } \\
\text { quest to build meaning in interaction with texts. }\end{array}$ \\
\hline 2017 & Soares & $\begin{array}{l}\text { The theory of cultural disability states that children } \\
\text { from the lower classes arrive at school with a } \\
\text { deficient language, which prevents them from } \\
\text { succeeding in learning activities in different fields of } \\
\text { knowledge. } \\
\text { When well worked at school, it is a facilitator to } \\
\text { develop writing, being the educator and his } \\
\text { educational practice a determining factor in this } \\
\text { learning process. }\end{array}$ \\
\hline 2018 & Lajolo & $\begin{array}{l}\text { Educational practices are necessary and } \\
\text { indispensable from the first three years of life. It is } \\
\text { important to follow the path in a linear way so that } \\
\text { the least visible results are possible. }\end{array}$ \\
\hline 2020 & Vieira & $\begin{array}{l}\text { Teaching practices in education aim to improve the } \\
\text { quality of education, and thus seek to develop the } \\
\text { functions of reading and writing. It is possible to } \\
\text { observe significant advances, however, we can still } \\
\text { notice that these practices are oscillating, in the } \\
\text { sense that they are sometimes directed to the } \\
\text { teaching of letters aiming at the beginning of } \\
\text { literacy, and sometimes promoting Children's } \\
\text { Literature. }\end{array}$ \\
\hline
\end{tabular}

Own source.

\section{Final considerations.}

From the reflections developed so far, it follows that the responsibilities of those who promote and develop education programs, highlight a greater objective, because it directly participates in the construction of a society, aiming at an innovative education and a more just and equal society. 
With all the visa, and referenced by the authors we understand that the teaching and learning process of reading and writing is a fundamental aspect in the educational field. Therefore, we understand that there is no possibility of full economic, political, social, cultural participation without the mastery of the written language, there is no possibility of participation in symbolic goods without access to reading as a cultural good, that is, there is no possibility of citizenship in the society in which we are inserted without the broad access of all to reading and writing, either in its functional role, as indispensable instruments in social, political and professional life, or in its cultural use, as a form of pleasure and leisure.

In this scenario, access to reading and writing as conditions for social and cultural participation is fundamentally a political process through which groups excluded from social, civil and political rights and cultural privileges have access to a symbolic asset that is denied them. But it is an indispensable capital in the struggle for the conquest of these rights and privileges, in the struggle for participation in power and in cultural instances of leisure and pleasure; in short, in the struggle for social transformation.

In this respect, we start from the premise that school is much more important to the working classes than to the privileged classes. For the latter, it has, above all, the function of legitimizing privileges already guaranteed by the origin of classes; for the working classes, the school is the instance where the necessary instruments can be acquired to fight against the unequal distribution of these privileges. It is from this perspective that we believe that it is crucial and urgent to develop formative proposals that will provoke reflection and, consequently, methodological changes. In which the activities are of great importance to develop the learning of reading and writing.

In this sense, and for the realization of this change and for a transforming school, Soares (2017, p. 114), states that the school can do, in this scenario in order to vitalize and adequately direct the progressive forces present in it, in order to guarantee the acquisition of knowledge and skills that instrumentalize them for participation in the process of social transformation.

Thus, a transformative school is a school aware of its political role in the fight against social and economic inequalities, and which therefore assumes the function of providing the working classes, through efficient teaching, with the instruments that will enable them to achieve broader conditions of cultural, political and social participation in the literate world in which they are inserted.

A transforming school does not accept the rejection of the language of students belonging to the lower classes, not only because it is as expressive and logical as prestigious language, but also, and above all, because this rejection would have an unacceptable political character, because it means a rejection of the class, through the rejection of its language.

For Vieira (2020), when commenting on the teacher's conceptions of language in educational discourse, the transforming school must coexist the articulation of 
knowledge produced by different theories and in different fields of knowledge, exposed above, in order to base language teaching on the process of social transformation towards a more just society. In this way, the relations between language and social class must be present, in a transformative school, in the objectives of teaching and learning of reading and writing, in the selection and organization of content, in the choice of teaching methods and procedures and in the determination of criteria for evaluating learning. For Freire (2011), the literacy teacher must act as an articulator of this teaching and learning process, and must reflect on the construction and reconstruction of his practice in literacy and reading rooms.

We hope that all that has been exposed in this study has provoked a reflection on the action of the school, the educational practices, and especially the commitment of each person involved in the learning process. What was reflected upon, allows for new perspectives of interaction on educational activities, thus allowing for successful actions in the school, giving opportunity to our students to build a society that is more valuable to the topic dealt with, in the sense and to produce knowledge through reading and writing.

And with all of the above, we highlight that the school needs to review strategies to transform and innovate its educational practices, so that students can learn with activities that allow them to develop their intellect. And for this to be possible, the significant contribution of government agencies to a greater and better structuring of Brazilian education becomes of fundamental importance. To enable and promote a coherent pedagogical practice and improvement of socio-cognitive capacities not fully developed, where it promotes and allows access to education in a democratic and equal way for all sectors of educational society.

\section{Conclusion.}

According to all the research and proven in the bibliographic reference in this work, we emphasize that when we consider the social educational practice in the learning of reading and writing, we should explore the concepts to better understand the cognitive processes and contexts related to the exercise of teaching in education. And such concepts according to Freire (2011), and others are timely, to better understand the learning process, enabling us to schemes of teaching that favor the construction of new knowledge and change concepts about other ways of interpreting the world.

It is within this discursive and interactive conception of language that we seek to dialogue with authors who bring concepts in which we can understand reading from the same perspective. And, therefore, we understand that it is crucial and urgent to develop formative proposals that will provoke reflections and, consequently, methodological transformations in the teaching of reading in the initial years of elementary school.

Thus, we highlight an important attention to the reorientation of reading practices at school so that, in fact, the school fulfills its role of developing a socio-educative formation. Finally, it is essential to highlight that formalised language is a beneficial step 
for collaborative and reflective teaching. They have favoured educational practices in order to improve them, because the educational process has vital meaning, because for the student to understand the world and to be able to participate in social reality it is necessary that he knows how to give meaning to words. Thus, innovative, meaningful and emancipatory practices are indispensable.

\section{References.}

BRASIL, Constituição (1988). Constituição da República Federativa do Brasil: 1988. Brasília, DF: Câmara dos Deputados, 2020.

BRASIL. (2020). Ministério da Educação (MEC). Planejando a próxima década: conhecendo as 20 metas do Plano Nacional de Educação. Brasília, DF. Disponível em: <h $\Sigma$ p://pne.mec. gov.br/conhecendo-o-pne>. Acesso em: 03 mai. 2020.

Demo, P. (1991). Pesquisa científica e educativa. São Paulo: Cortez.

Freire, P. (1988). A importância do ato de ler: em três artigos que se completam. 22.ed. São Paulo: Autores Associados: Cortez.

Freire, P. (2011). Pedagogia da autonomia: saberes necessários à prática educativa. Ed. 43. São Paulo: Paz e Terra.

Lajolo, M. (2018). A importância do ato de ler. São Paulo: Moderna.

Mendonça. O. S. (2011). Alfabetização ou letramento? Equívocos e consequências na sala de aula. Revista Acolhendo a Alfabetização nos Países de Língua Portuguesa, Brasil, São Paulo, volume 1, n. 11, pp. 28 - 48.

Soares, M. (2017). Linguagem e Escola: uma perspectiva social. São Paulo: Editora Contexto.

Soleto, D. (2012). Resenha da obra: Freire, Paulo. A Importância do Ato de Ler - em três artigos que se completam. São Paulo: Cortez Editora \& Autores Associados,1991. (Coleção Polêmicas do Nosso Tempo, v 4)-.Revista Científica Fac Mais, Volume. II, Número 1. Ano 2012/2 Semestre. ISSN 2238-8427.

Vieira, T.A. (2020). As concepções de linguagem no discurso do professor alfabetizador nas Séries Iniciais do Ensino Fundamental I. 2020. 117f Dissertação (Mestrado) - Universidade Federal do Ceará, Programa de Pós-graduação em Linguística, Fortaleza. 